\title{
Hypocholesterolemic Activity of Desalted Miso in Rats Fed an Atherogenic Diet
}

\author{
Masaharu HoRII*, Takashi IDE* , Kenji KawASHIMA ${ }^{* *}$ and \\ Tadashi YамAмото ${ }^{* * *}$ \\ * National Food Research Institute, Ministry of Agriculture, Forestry \\ and Fisheries, 2-1-2 Kannondai, Tsukuba, Ibaraki 305 \\ ** Food $R$ \& D Center, Japan Tobacco Inc., 6-2, Umegaoka, Midori-ku, \\ Yokohama, Kanagawa 227 \\ *** Aomori Field Crops and Horticultural Experiment Station, Rokunohe, \\ Kamikita-gun, Aomori 033
}

\begin{abstract}
Effect of dietary miso on the cholesterol metabolism was examined in rats fed the diet containing $0.5 \%$ cholesterol and $0.15 \%$ sodium cholate. The inclusion of $20 \%$ desalted miso to the atherogenic diet significantly decreased the concentration of serum cholesterol throughout the 30 days experimental period. Serum triglyceride and phospholipid as well as hepatic lipid concentrations at the time of sacrifice ( 30 days) were in no way affected by dietary miso. The ingestion of the miso preparation doubled the fecal excretion of acidic steroids, while it increased only slightly that of neutral steroids. The dietary miso appeared to exert the potent hypocholesterolemic activity primarily through the enhancement of the catabolism of cholesterol to bile acids in rats fed an atherogenic diet.
\end{abstract}

It has been well demonstrated that soybean in addition to several kinds of cereal beans cause significant reduction of serum cholesterol in rats fed a high-cholesterol diet ${ }^{1)-4)}$. The components that exert the potent hypocholesterolemic activity have been isolated from soybean and thus accounted for the cholesterol lowering effect ${ }^{5)-9)}$. Thus, the ingestion of soybean products hopefully reduce the incidence of atherosclerosis not only in experimental animals but also in humans.

There are several kinds of soybean fermentation products which have been consumed by Japanese population. The fermentation processes cause modification or degradation of the components included in soybean ${ }^{10) \sim 13}$. However, little is known whether these changes modify the characteristic nature of soybean to affect the lipid metabolism in experimental animals. In this context, we currently examined the effect of dietary miso, a fermentation product of soybean, on the cholesterol metabolism in rats fed an atherogenic diet. From the consideration that high contents of $\mathrm{NaCl}$ which is usually seen in miso may exert untoward effect on the lipid metabolism of the animals and thus make the interpretation of the results obtained difficult, the desalted product was employed in this trial.

\section{Materials and Methods}

\section{Animals and diets}

Male Sprague-Dawley rats (4 weeks of age) obtained from Charles River Japan Co., Kanagawa were fed a commercial non-purified diet (Type NMF, Oriental Yeast Co., Tokyo). After 7 days of acclimation to our housing conditions, the rats were randomly divided into two groups of 6 animals and fed the atherogenic purified experimental diets containing both $0.5 \%$ cholesterol and $0.15 \%$ sodium cholate. The ingredients and fatty acid compositions of the diets are summarized in Table 1. The diet for a control group contained $20 \%$ casein (purity 94.5\%), 10\% lard and $a$ corn starch in addition to sucrose as protein, 
Table 1 Ingredients and fatty acid compositions of atherogenic experimental diets

\begin{tabular}{lcc}
\hline & \multicolumn{2}{c}{ Diets } \\
\cline { 2 - 3 } Ingredients & $\begin{array}{c}\text { Control } \\
\text { (weight } \% \text { ) }\end{array}$ \\
\hline Miso (desalted) & - & 20 \\
Casein & 20 & 14.78 \\
$\alpha$-Corn starch & 15 & 15 \\
Sucrose & 41.65 & 32.47 \\
Lard & 10 & 4.4 \\
Cellulose & 8 & 8 \\
Cholesterol & 0.5 & 0.5 \\
Sodium cholate & 0.15 & 0.15 \\
Mineral mixture & 3.5 & 3.5 \\
Vitamin mixture & 1.0 & 1.0 \\
Choline bitartrate & 0.2 & 0.2 \\
\hline
\end{tabular}

Fatty acid composition (weight $\%$ )

$\begin{array}{lrr}14: 0 & 1.51 & 0.92 \\ 16: 0 & 21.82 & 17.66 \\ 16: 1 & 4.06 & 2.37 \\ 18: 0 & 10.95 & 7.74 \\ 18: 1 & 46.52 & 34.55 \\ 18: 2 & 12.40 & 30.41 \\ 18: 3 & 1.94 & 5.82 \\ P / S^{*} & 0.418 & 1.377\end{array}$

* The ratio of polyunsaturated to saturated fatty acids

lipid and available carbohydrate sources, respectively. Cellulose as a non-available carbohydrate (dietary fiber) source was added to the experimental diets at $8 \%$ levels. Vitamin and mineral mixtures, the compositions of which were the same as recommended by American Institute of Nutrition ${ }^{14)}$, were obtained from Nihon Nosan Kogyo K.K., Tokyo. The lyophilized preparation of desalted miso (a kind gift from Marudai, K.K., Niigata) containing less than $2 \% \mathrm{NaCl}$ was added to the experimental diet at $20 \%$ level. As the miso preparation contained $26.1 \%$ protein and $28.1 \%$ lipid, the amounts of casein and lard in the diet were reduced and made $100 \%$ with sucrose. Thus, these experimental diets served similar amounts of protein $(18.90 \%$ and $19.19 \%$ for the control and miso diets, respectively) and lipid
(10.00\% and $10.02 \%$, respectively). Although we have not analyzed contents and compositions of the materials other than protein and lipid of lyophilized miso, the preparation presumed to contain significant amounts of components other than available carbohydrate (starch and sugar) including dietary fiber. Thus, the dietary energy served from carbohydrate sources might be somewhat less in the miso diet compared to the control diet. As miso lipid contained considerable amounts of polyunsaturated fatty acids (linoleic and linolenic acids), the ratio of polyunsaturated to saturated fatty acids $(\mathrm{P} / \mathrm{S})$ in the diet containing miso was considerably higher than that in the control diet containing lard as a sole lipid source. Phytosterol content of the diet containing miso was $23.9 \mathrm{mg} / 100 \mathrm{~g}$. Rats were fed these experimental diets for 30 days. Small volumes (less than $0.1 \mathrm{~m} l$ ) of blood were withdrawn from tail vein periodically (at 7,14 and 23 days) during the feeding period for the analysis of serum cholesterol. Feces were also collected for 2 days at $12 \sim 14,21 \sim 23$ and $28 \sim 30$ days of the feeding period. At the termination of the experimental period, rats were lightly anesthetized with diethylether and blood was withdrawn from vena cava. Livers were quickly excised.

\section{Lipid analyses}

Hepatic and serum lipids were extracted and purified as described by FoLCH et al. ${ }^{15)}$. Cholesterol, triglyceride and phospholipid in the lipid extracts except for serum cholesterol were chemically determined by the methods reported by us previously ${ }^{16)}$. Serum cholesterol was enzymatically determined by a commercial assay kit (Cholesterol C-test, Wako Chemical, Osaka).

\section{Fecal steroid analysis}

Fecal neutral and acidic steroids were extracted with ethanol under reflux. Neutral steroids (cholesterol and coprostanol) and acidic steroids (bile acids) were determined by a gas-liquid chromatograph using $5 a$-cholestane and nordeoxycholic acid as the internal standards, respectively ${ }^{17)}$.

Statistical analysis 
Data were analyzed by a Student's t-test and significant differences of the means were inspected at $p<0.05$.

\section{Results}

Dietary miso did not affect the daily food intake and growth of animals. The diet containing miso revealed a potent hypocholesterolemic activity (Fig. 1). The serum cholesterol concentrations in rats fed miso were approximately one-half those in the control group during the entire experimental period.

Serum and hepatic lipid concentrations at the time of sacrifice (30 days) were summarized in Table 2. Although dietary miso apparently reduced the serum cholesterol concentration, it was in no way effective to alter the triglyceride and phospholipid concentrations. Hepatic cholesterol concentration appeared to be reduced slightly by dietary miso. However, the difference was statistically insignificant. There were no significant differences in the hepatic triglyceride and phospholipid concentrations between the two groups of rats.

Feces were occasionally collected for 2 days during the 30 days experimental period and excretion of neutral and acidic steroids were determined (Table 3 ). The inclusion of miso

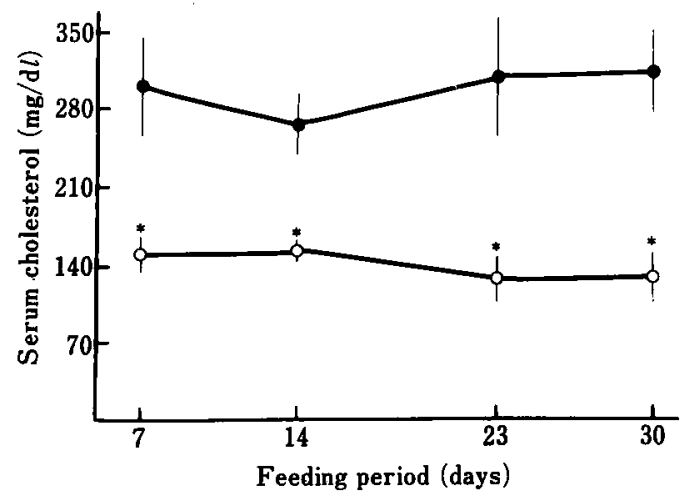

Fig. 1 Effect of desalted miso on the concentration of serum cholesterol in rats fed an atherogenic diet. $O$, miso ; , control. "Significantly different from the corresponding value in rats fed control diet at $\mathrm{P}<$ 0.05 .
Table 2 Serum and hepatic lipid concentrations in rats fed desalted miso for 30 days

\begin{tabular}{lcc}
\hline & \multicolumn{2}{c}{ Diets } \\
\cline { 2 - 3 } & Control & Miso \\
\hline Serum lipids $(\mathrm{mg} / \mathrm{d} l)$ & & \\
Cholesterol & $313 \pm 38$ & $127 \pm 24^{*}$ \\
Triglyceride & $217 \pm 40$ & $236 \pm 53$ \\
Phospholipid & $222 \pm 17$ & $202 \pm 20$ \\
\hline Hepatic lipids (mg/g) & & \\
Cholesterol & $61.7 \pm 4.2$ & $50.0 \pm 4.8$ \\
Triglyceride & $87.8 \pm 6.0$ & $90.4 \pm 6.6$ \\
Phospholipid & $25.7 \pm 0.8$ & $28.0 \pm 1.0$ \\
\hline
\end{tabular}

Values represent means $\pm S E$ of 6 rats.

* Significantly different from the value in rats fed control diet at $\mathrm{p}<0.05$.

in the experimental diet apparently increased the amounts of feces excreted. Dietary miso doubled the daily excretions of acidic steroids during the entire experimental period. Although excretions of neutral steroids in rats fed miso also considerably increased, the significant difference of the parameter was only detectable in the early phase of the feeding period $(12 \sim 14$ days).

The steroid compositions of feces collected at $28 \sim 30$ days of the experimental period are summarized in Table 4. The dietary miso considerably affected the composition of fecal acidic steroids. The percentage value for cholic acid considerably decreased in rats fed miso. The decrease in the value was compensated by the increases in those of lithocholic, hyodeoxycholic or ursodeoxycholic as well as $\beta$ muricholic acids. The occurrence of bacterial hydrogenation of cholesterol to coprostanol appeared to be minimal in the control group. On the other hand, dietary miso apparently increased the proportion of coprostanol in the fecal neutral steroid. The similar results were obtained in the feces collected at $12 \sim 14$ and $19 \sim 21$ days of the experimental period.

\section{Discussion}

It has been observed that soybean as well as several kinds of cereal beans caused significant 
Table 3 Effect of desalted miso on the fecal excretions of acidic and neutral steroids

\begin{tabular}{cccc}
\hline \hline $\begin{array}{c}\text { Feeding period } \\
\text { (days) }\end{array}$ & $\begin{array}{c}\text { Feces excreted } \\
\text { (g/day) }\end{array}$ & $\begin{array}{c}\text { Acidic steroids } \\
\text { (mg/day) }\end{array}$ & $\begin{array}{c}\text { Neutral steroids } \\
\text { (mg/day) }\end{array}$ \\
\hline $\begin{array}{l}\text { 12 14 days } \\
\text { Control }\end{array}$ & $2.02 \pm 0.08$ & $16.8 \pm 0.6$ & $19.3 \pm 2.3$ \\
$\quad$ Miso & $2.96 \pm 0.12^{*}$ & $30.2 \pm 1.7^{*}$ & $29.6 \pm 2.9^{*}$ \\
19 21 days & & & \\
Control & $2.38 \pm 0.12$ & $21.7 \pm 2.0$ & $26.8 \pm 2.4$ \\
Miso & $3.44 \pm 0.21^{*}$ & $40.0 \pm 3.3^{*}$ & $30.4 \pm 3.1$ \\
$28 \sim 30$ days & & & \\
Control & $2.38 \pm 0.04$ & $22.6 \pm 1.2$ & $24.4 \pm 2.6$ \\
Miso & $3.57 \pm 0.19^{*}$ & $40.0 \pm 0.19^{*}$ & $31.4 \pm 3.8$ \\
\hline
\end{tabular}

Values represent means $\pm S E$ of 6 rats. * Significantly different from the value in rats fed control diet at $\mathrm{p}<0.05$.

Table 4 Effect of desalted miso on the compositions of fecal acidic and neutral steroids

\begin{tabular}{lcc}
\hline \hline & \multicolumn{2}{c}{ Diets } \\
\cline { 2 - 3 } & \multicolumn{2}{c}{$\begin{array}{c}\text { Control } \\
\text { (weight \%) }\end{array}$} \\
\hline $\begin{array}{l}\text { Acidic steroids } \\
\text { Lithocholic acid }\end{array}$ & $0.96 \pm 0.44$ & $2.82 \pm 0.61^{*}$ \\
Deoxycholic acid & $36.7 \pm 3.7$ & $39.9 \pm 3.0$ \\
Hyodeoxycholic + & $10.5 \pm 1.5$ & $16.4 \pm 1.0^{*}$ \\
Ursodeoxycholic acids & & \\
Cholic acids & $28.2 \pm 3.9$ & $8.9 \pm 1.9$ \\
$\alpha$-Muricholic + & $9.3 \pm 1.4$ & $10.0 \pm 0.4$ \\
a-Muricholic acids & $14.4 \pm 1.1$ & $22.0 \pm 2.3^{*}$ \\
$\beta$-Muricholic acid & & \\
\hline Neutral steroids & $3.23 \pm 1.38$ & $15.6 \pm 5.3^{*}$ \\
Coprostanol & $96.8 \pm 1.4$ & $84.4 \pm 4.9^{*}$ \\
\hline Cholesterol & &
\end{tabular}

Values represent means $\pm \mathrm{SE}$ of 6 rats. ${ }^{*} \mathrm{Sig}$ nificantly different from the value in rats fed control diet at $p<0.05$.

reduction of serum cholesterol in rats fed a high-cholesterol diet ${ }^{1) \sim 4}$. This study also demonstrated that miso, a fermentation product of soybean, retained the hypocholesterolemic activity in the experimental animal (Fig. 1 and Table 2). Dietary miso dependent reduction of serum cholesterol levels accompanied the increased fecal excretion of acidic steroids (Table 3 ). Thus, dietary miso presumably accelerated the catabolism of cholesterol to bile acids and thus reduced the cholesterol concentration in the serum. As increases in the excretion of neutral steroids in rats fed miso were rather moderate and insignificant except for one occasion (Table 3), the reduced intestinal absorption of cholesterol could not be regarded as a determinant factor for the cholesterol lowering effect of miso observed currently.

Several components of soybean now have been demonstrated to exert potent hypocholesterolemic activities. Lipid components including triglyceride ${ }^{17)}$ and phospholipid ${ }^{8)}$ containing high levels of polyunsaturated fatty acid as well as phytosterols ${ }^{9)}$ could lower the serum cholesterol in rats as well as in humans. Fatty acid composition of miso was resembled with that reported for soybean (data not shown $)^{17}$. Thus, the fermentation process does not seem to modify the fatty acid moieties of soybean lipids significantly. As miso lipid retained the high proportions of $n-6$ (linoleic acid) and n-3 (linolenic acid) polyunsaturated fatty acids, the ratio of polyunsaturated to saturated fatty acid ( $\mathrm{P} / \mathrm{S}$ ratio) in the diet containing miso is considerably higher than that in the control diet containing lard as a sole source of dietary lipid (Table 1). The difference in the $\mathrm{P} / \mathrm{S}$ ratio between the two 
diets may account for the cholesterol lowering effect of miso observed currently. The phytosterol content of the miso preparation appeared to be too low to exert any significant effect on serum cholesterol ${ }^{9}$.

There are a number of studies to demonstrate the cholesterol lowering effect of soy protein $^{7)}$ and saponin ${ }^{5 / 6)}$. It is not clear whether the fermentation process for the production of miso modify the propensities of these components to alter the lipid metabolism in experimental animals. However, it is possible that these components in addition to lipid moieties in miso retain the meritorious propensities and thus contribute to the cholesterol lowering effect of the fermentation product.

Many kinds of dietary fiber have been demonstrated to decrease the serum cholesterol concentrations in experimental animals and humans ${ }^{18) 19}$. Increased excretion of feces in rats fed miso indicate the presence of considerable amounts of non-digestible fiber in the miso preparation employed currently. Although information regarding the effect of fiber contained in soybean on cholesterol metabolism is rather scanty, it would also be a candidate responsible for the cholesterol lowering effect of dietary miso.

The dietary miso affected the fecal bile acids not only quantitatively but also qualitatively. The percentages of bile acids derived from chenodeoxycholic acid either primarily through the hepatic metabolism ( $\beta$-muricholic acid) or secondly through the metabolism by intestinal bacteria (lithocolic, hyodeoxycholic and ursodeoxycholic adids) except those for $\alpha$ - and $\omega$-muricholic acids increased. On the other hand the percentage of cholic acid decreased and that of the secondary metabolite (deoxycholic acid) was unchanged. The results indicate that the catabolism of cholesterol to chenodeoxycholic acid rather than to cholic acid is enhanced in rats fed miso. The conposition of fecal neutral steroids was also affected by dietary miso. Increase in the proportion of coprostanol, a bacterial hydrogenation product of cholesterol, in rats fed miso indicated that the dietary miso modified the composition and (or) the activities of intestinal flora.

In conclusion, this study demonstrated a potent hypocholesterolemic activity of dietary miso in rats fed an atherogenic diet. The miso appeared to increase the catabolism of cholesterol to bile acids and thus reduced the serum cholesterol in the experimental animal.

Authors wish to thank Central Miso Research Institute for the financial support to carry out the present study.

\section{References}

1) Chang, K.C., Ethen, S., Harrold, R. and Brown, G.: Nutr. Rept. Int., 33, 659 (1970).

2) Munoz, J.M., SANdSTEAd, H.H., Jacob, R.A., Logan, G.M., Reck, S.J., KLevay, L.M., Dinitzis, F.R., InGLetT, G.E. and ShuEY, W.C. : Am. J. Clin. Nutr. 32, 580 (1979).

3) Jenkins, D.J.A., Wong, G.S., Patten, R., BIRD, J., Hall, M., BuCKLEY, B.C., McGuire, V., ReicherT, R. and LitTLE, J.A. : Am. J. Clin. Nutr. 38, 567 (1983).

4) Sharma, R.D.: Nutr. Rept. Int. 33, 669 (1986).

5) Oakenfull, D.G., Topping, D.L., Illman, R.J. and FEnwiCk, D.E. : Nutr. Rept. Int. 29, 1039 (1984).

6) Sidhu, G.S., Upson, B. and Malinow, M.R. : Nutr. Rept. Int. 35, 615 (1987).

7) Sugano, M.: "Animal and vegetable proteins in lipid metabolism and atherosclerosis", edited by GIBNEY, M.J. and KRITChevsky, D. (Alan R. Liss Inc., New York), p. 51 (1983).

8) Murata, M., Imaizumi, K. and Sugano, M. : J. Nutr. 115, 994 (1985).

9) Grundy, S.M. and MoK, H.Y.I. : "Lipoprotein metabolism", edited by GRETEN, H. (Springer-Verlag, . Berlin), p. 112 (1976).

10) Kiuchi, K., Suzuki, O., Ohta, T., Sato, E. and Eвine, H.: Nippon Shokuhin Kogyo Gakkaishi. 25, 224 (1978).

11) Kiuchi, K., OHTA, T., Ishima, T., TAKabayashi, T. and Ebine, H.: Nippon Shokuhin Kogyo Gakkaishi 24, 295 (1977). 
12) Sugimura, K., Taira, H., Ebisawa, H. and SAKURAI, Y.: Eiyo to Shokuryo 14, 44 (1961).

13) Katagiri, M. and Shimizu, S.: Nippon Shokuhin Kogyo Gakkaishi 33, 667 (1986).

14) American Institute of Nutrition: $J$. Nutr. 107, 1340 (1977).

15) Folch, J., Lee, M. and Slone-Stanley, G.H. : J. Biol. Chem. 226, 497 (1957).

16) Ide, T., Okamatsu, H. and Sugano, M. : $J$. Nutr. 108, 601 (1978).

17) Sugano, M., IDE, T., Kohno, M., Watanabe, M., Cho, Y.-J. and Nagata, Y. : Lipids 18, 186 (1983).

18) KAY, R.M. : J. Lipid Res. 23, 221 (1982).

19) KRItchevsky, D. : Scand. J. Gastroenterol. 22 suppl. 129, 213 (1987)

(Received Dec. 1, 1988)

高コレステロール・胆汁酸食摄取ラットにおける 脱塩みその血清コレステロール低下作用

堀井正治*・井手 隆*・川島賢二**・山本忠志***

(“農林水産省食品総合研究所, ${ }^{* *}$ 日本たばこ食生活研 究所, $* * *$ 青森県畑作園芸試験場)

高コレステロール・胆汁酸食摄取ラットのコレステロ
ール代謝に与える脱塩みその効果を調べた。雄 Sprague-Dawley 系ラットを 0.5\%コレステロール, $0.15 \%$ コール酸ナトリウムを含む食慨で 30 日間飼育し た. 飼育開始後 7,14 および 23 日目に尾静脈より血液 を採取し，血清コレステロール濃度を測定した。 また䔬 を 12,21 ，および 28 日目に 2 日間採取し，ステロイド の分析を行った．30日目にラットを屠殺し血清，肝膱 の脂質分析を行った．食餌中に脱塩みそを $20 \%$ 添加す ることにより血清コレステロール濃度の低下が認められ た. みそ添加群の血清コレステロール濃度は全実験期間 中対照群の約半分であった. 屠殺時の血清トリグリセリ ド, リン脂質濃度および肝䜟脂質濃度には, みその効果 は認められなかった，顀中への胆汁酸排泄は，みその食 餌への添加により約二倍に増加した. 中性ステロイドの 排泄もみそにより増加するがその程度は小さく有意差は 認められなかった. 以上のことからみその食䬣への添加 はコレステロールの胆汁酸への異化とその体外への排泄 を增加させることにより血清コレステロール濃度を低下 させるものと思われた.

\section{新刊稆介}

食物のバイオテクノロジー

貝沼圭二編

本書は, 農畜水産食品の生産から加工にいたる過程で 進められているバイオテクノロジー研究の最新の現状と その将来性について分かりやすく解説した好著である. その内容は，先端技術，稲，果実・野菜，畜産，水産， 発酵食品, 甘味料, 食品加工, 夢の植物の各項目毎に, その分野で実施されているバイオテクノロジーが解説さ れている.

$15 \times 21 \mathrm{~cm}, 168$ 頁 1989 年刊,

ISBN 4-8391-0331-3

明文晋房 2200 円 